\title{
HOSPITALITY INDUSTRY - REDEFINING LEISURE AND RECREATION
}

\author{
Manoj Sharma*
}

We live in an age of cocooning: there is a tangible need to feel secure and pampered in a world of terrorism and uncertainty. The latest trend in travel is not high-altitude trekking or exploring remote and difficult reaches - it is the emergence of hotels as complete travel destinations. The accommodation industry is rising to the challenge, bolstering city hotels with extra facilities to fit the urban oasis template and creating resorts so complete it almost becomes redundant to go out.

In a nutshell, sightseeing is out and beautiful "residential" hotels are in.

The modern hotel junkie may display loyalty to certain groups (Aman, Banyan Tree, Four Seasons, Angsana - the names are tossed about as showily as designer clothing labels) but there is an element of fickleness, too - fashion was ever thus, alent to the next big thing. In earlier days, when travel of any kind was a sensational adventure and most of us remained faithful to destinations and favourite lodgings, it was rare to venture anywhere new. As a child in 1950s England, my family stayed at the same Brighton boarding house year after year and we were assigned "our" table in the dining room - it would have been unthinkable to go anywhere else. Some of the traditionalists loved certain hotels

* Lecturer,School of Hospitality and Tourism, Victoria University,Melbourne, Australia Email:manoj.sharma@vu.edu.au 
so much they simply moved in, becoming as much a fixture as the bellboy or the lift operator.

The character played by Gene Hackman in The Royal Tenenbaums movie is thrown out of his New York hotel after many years for not keeping his bill up-todate - he's outraged but later returns - as a humble uniformed employee. He simply couldn't function in the real world.

Writer Pino Cacucci and photographer Thierry Bouet published a book titled Hotel People a few years ago and the former claimed "hotels are good to put lives into parentheses: they are oases and havens where one can enjoy fully the fleeting time of each day, without letting the thousand duties imposed by a normal existence erode and gnaw it away". In short, no concerns about catering or shopping for such trivialities as shampoo, changing light-bulbs or sheets, or waiting in for the television repairman.

Cacucci is fascinated by writers who have lived in hotels - Ernest Hemingway at the Hotel Ambos Mundos in Havana, Jean-Paul Sartre and Simone de Beauvoir at the Lovisiane in Paris - and found "no better place ... to give life to the characters of their works".

Coco Chanel lived for four decades at The Ritz in Paris, Howard Hughes resided at the Desert Inn in Las Vegas, bon vivant Peter Jansen kept a suite for years at The Windsor in Melbourne and at New York's Chelsea, tortured writers and artists and assorted eccentrics still live, and occasionally die, in company with the ghosts of Dylan Thomas, Sid Vicious et al.

The modern hotel junkie does move on and even goes home, however reluctantly. This breed stays at the hotels everyone is talking about, the temples of design, the character-laden (but freshly spruced and re-plumbed) colonial piles and the spa resorts with Tibetan bell therapies and Balinese bridal scrubs sitting casually on the make-over menu.

There is no longer any cachet in boasting of destinations visited - let's face it, there are no new frontiers to explore. The trophy is the accommodation experience, the first-on-your-block challenge of getting to the latest hot hotel virtually before the (Italian marble) tiles have been grouted. The dinner party trophies are not of sunrises over the Andes or the symmetry of the Taj Mahal but Banyan Tree private pools and Hayman Island lagoons.

The language of accommodation has changed its tune. Rooms are sanctuaries, even wombs, not somewhere to unpack and head out of but to nestle into. 
Properties that have got the message are spending zillions of dollars on enormous $\mathrm{TV}$ s with the latest in computer capabilities (no one wants to step down to the basement business centre - which, come to think of it, has been turned into a spa). Brochures boast of $100 \mathrm{~cm}$ plasma screens and goosedown duvets as if they're inclusions in a sales catalogue - which perhaps they are. Hotel cocooners staying in such design-conscious properties as Palazzo Versace on the Gold Coast or Banyan Tree resorts in Asia frequently order "in-house" furniture, manchester and fittings to be delivered home. Buy tableware, signature spa products, cushions, throws and other accoutrements to create your own minihotel at home.

Bathrooms have sprung "shower temples", oceanic tubs, hands-free phones and flat-screen TVs embedded above the tub. In new top-star hotels, bathrooms are about 40 per cent the size of the guestroom and many designers are refocusing priorities, perhaps sacrificing a bigger balcony for a bathroom that has a tub with a view. The attention is in the detail - the 250-thread Egyptian cotton sheets and aromatherapy burner versus yesterday's floral bedspread and bowl of potpourri.

Hotel dining and room service menus have, at last, transcended the soup-ofthe-day and club-sandwich doldrums. Celebrity chefs are designing hotel menus (and sometimes cooking in-house - witness David Thompson's Michelin-starred Thai restaurant, Nahm, at The Halkin in Belgravia) and hotel bars and clubs are part of the cocooning experience, too, often becoming style destinations in their right — out-there designer Philippe Starck, for instance, designed the funky Felix night-spot and restaurant atop the otherwise conservative Hong Kong Peninsula.

We can thank the hotel world for the now-ubiquitous term "hip". The push started in 1988 when lan Schrager opened The Royalton in New York and the press and design fraternity dubbed it hip — there's some debate if that was an acronym of "highly individual place" or if the epithet was borrowed from the fashion-clubmusic circuit. Either way, the tag has stuck. The Royalton broke new ground with its circular padded cocktail lounge, curved corridors and nightclub lighting Schrager was pleased to inform young guests that it didn't look like somewhere their parents would stay. Enter the era of the "in" keeper.

But what a difference a new century makes. Hip is out and comfort is in maximalism is back, and so is the boudoir. More is more, the pundits declare. The post-9/11 ethos is all about home and travellers want places that reflect luxury and layers of detail, from squashy cushions by the hill-load and pillow menus (feather, foam, lavender-filled, anti-snore or non-allergenic - the range is astonishing) to the world's most desirable soaps and lotions. 
Hotels such as the Meurice in Paris illustrate the maxi trend perfectly. Its recent extraordinary refurbishment is touted to have cost $\$ U S 400,000(\$ 517,800)$ per room, some of it spent on under-bath heating to keep the tub water warm, mistfree mirrors, silk curtains that billow like debutante gowns, fabulous antiques and palatial chandeliers and, well, luxury at every level. A hotel, in short, that wants guests to feel right at home - gosh, we wish.

A bevy of rooms with a point of view.

Here is an insight into the latest on where hotels are headed:

Couture Hotels: Giorgio Armani is teaming with a Dubai-based company to launch a portfolio of 10 luxury hotels and four resorts over the next seven years. London, Tokyo and Shanghai are among the favoured destinations. Naturally, the style-conscious hotels will be equipped with Armani Casa furniture and homewares and signature toiletries. Armani is following where other fashion gurus have led - hail Anouska Hempel's Blakes in London and Amsterdam, Todd Oldham's The Hotel in Miami, Palazzo Versace on the Gold Coast and the Ferragamo family's collection in Florence, including a two-suite apartment in a grand palazzo. Cerutti Hotels will open its first accommodation house this year and there's a Bulgari property, in conjunction with Marriott, on the books for Milan (in a converted nunnery) and in Bali in 2005.

Disposable Hotels: The lce Hotel Quebec, made each year from ice and packed snow, opens from January to the spring thaw at the end of March. Management claims "the four feet-thick walls act as excellent windbreaks". The original ice hotel is in Swedish Lapland where guests recline in sleeping bags on reindeer skins on timber-topped ice platforms. Meanwhile, in decidedly more tropical climes, the Havana apartment-style resort at Port Douglas, opening in 2005, will have a below-zero lce Bar.

Baby Grands: The Leading Hotels of the World introduced a "small" category in 1999, reflecting that mini need not mean diminished service or facilities. There are 25 new members in the 120-strong portfolio, including such grand options as an Irish castle, a French chateau and, intriguingly, an Italian spa hotel with "reconditioning and beauty" as an official part of its name. Now, that is service.

Spa Horizons: Integrated resorts with compound-like architecture and cottagesized villas (ideally featuring private plunge pools), treatments galore, yoga and meditation classes and easy-access watersports are geared to top-league cocooners. Overwater bungalows are the latest must-have lodgings. Favoured 
destinations: Maldives, Mauritius, Seychelles, smaller islands of French Polynesia, southern Thailand and Bali.

\section{References:}

1. International Journal of Contemporary Hospitality Management

2. Comell Hotel School Monthly

3. Leading Hotels of the World Magazine

4. Jumeriah Group of Hotels

5. Giorgio Armani Boutique Hotels

6. Ice Hotel Quebec 